Etihad: Journal of Islamic Banking and Finance

Vol. 1, No. 1, Januari - Juni 2021: 23-36

\title{
PENGARUH KOMITE AUDIT, GOOD CORPORATE GOVERNANCE DAN WHISTLEBLOWING SYSTEM TERHADAP FRAUD BANK UMUM SYARIAH DI INDONESIA PERIODE 2016-2019
}

\author{
Phuji Maisaroh ${ }^{1}$, Maulida Nurhidayati ${ }^{2}$ \\ 1,2Institut Agama Islam Negeri Ponorogo, Indonesia \\ Email: mayphuji99@gmail.com, nurhidayati@iainponorogo.ac.id
}

\begin{abstract}
Fraud relates to fraudulent acts committed deliberately through bank facilities and resulting in losses. Although the role of the audit committee has been established, Good Corporate Governance has generally been well implemented, and has carried out a fairly good internal control function through the Whistleblowing System, the fulfillment of these components has not significantly been able to overcome fraud. Such an interesting condition to be related to the theory of Rezaae and Ajeng Wind. This study is intended to examine the effect of the audit committee, Good Corporate Governance, and the Whistleblowing System on fraud either partially or simultaneously. Sharia Commercial Banks for the period 2016-2019 in Indonesia were selected as the population using saturated sampling techniques, there are 14 Islamic Commercial Banks with 56 units of analysis used in this study. Ordinal logistic regression model was chosen as an analysis technique with SPSS 21 software as an analysis tool. The results of this study indicate that the variable composition of the independent audit committee, tenure of the audit committee and good corporate governance has a significant negative relationship to fraud. Meanwhile, the audit committee meeting variables and the Whistleblowing System have a negative and insignificant effect on fraud. The independent variable composition of the audit committee, audit committee meetings, tenure of the audit committee, Good Corporate Governance, and the Whistleblowing System is able to explain the variation of fraud by $29 \%$ while the remaining $71 \%$ is explained by other variables outside the research model. The low level of influence may be due to the inadequate follow-up of the audit committee meetings and the lack of independence of the internal auditors in managing fraud reports. So that Sharia Commercial Banks must optimize the function of the anti-fraud division and present the division in holding meetings, as well as increase the independence of the internal auditors in managing reports of suspected fraud that are submitted through the Whistleblowing System.
\end{abstract}

Keywords: probability, fraud, independence, self assessment, ordinal logistic regression.

Abstrak: Fraud berkaitan dengan tindakan kecurangan yang dilakukan secara sengaja melalui sarana bank dan mengakibatkan kerugian. Meskipun peranan komite audit telah terbentuk, Good Corporate Governance secara umum telah diterapkan dengan baik, serta menjalankan fungsi pengendalian internal melalui Whistleblowing System yang cukup baik, namun pemenuhan komponen-komponen tersebut tidak secara signifikan mampu mengatasi fraud. 
Kondisi yang demikian menarik untuk dihubungkan dengan teori Rezaae dan Ajeng Wind. Penelitian ini dimaksudkan untuk menguji pengaruh komite audit, Good Corporate Governance, dan Whistleblowing System terhadap fraud baik secara parsial maupun simultan. Bank Umum Syariah di Indonesia periode 2016-2019 dipilih sebagai populasi dengan menggunakan teknik sampling jenuh, ada 14 Bank Umum Syariah dengan 56 unit analisis yang digunakan dalam penelitian ini. Model regresi logistik ordinal dipilih sebagai teknik analisis dengan software SPSS 21 sebagai alat bantu analisis. Hasil penelitian ini menunjukkan variabel komposisi komite audit independen, masa tugas komite audit dan Good Corporate Governance memiliki hubungan yang negatif signifikan terhadap fraud. Sedangkan variabel rapat komite audit dan Whistleblowing System berpengaruh negatif tidak signifikan terhadap fraud. Variabel independen komposisi komite audit, rapat komite audit, masa tugas komite audit, Good Corporate Governance, dan Whistleblowing System mampu menjelaskan variasi fraud sebesar $29 \%$ sedangkan $71 \%$ sisanya dijelaskan oleh variabel lain diluar model penelitian. Rendahnya pengaruh yang diberikan tersebut kemungkinan disebabkan oleh kurang optimalnya tindak lanjut dari rapat komite audit yang diselenggarakan serta kurangnya independensi auditor internal dalam mengelola laporan fraud. Sehingga Bank Umum Syariah harus mengoptimalkan fungsi divisi anti fraud dan menghadirkan divisi tersebut dalam penyelenggaraan rapat, serta meningkatkan independensi auditor internal dalam mengelola laporan dugaan fraud yang masuk melalui Whistleblowing System.

Kata Kunci: probabilitas, kecurangan, independensi, self assessment, regresi logistik ordinal.

\section{PENDAHULUAN}

Perkembangan Bank Umum Syariah diiringi dengan permasalahan-permasalahan yang semakin kompleks. Permasalahan yang mendasari pengembangan bank syariah salah satunya terkait dengan kurangnya sumber daya manusia yang mumpuni sesuai bidang ekonomi syariah (Sodiq, 2017). Sejalan dengan hal tersebut, maka perkembangan perbankan syariah akan jauh lebih baik jika karyawan bank syariah memiliki komitmen bersama untuk senantiasa menjalankan prinsip-prinsip syariah. Sehingga reputasi yang dibangun oleh bank dapat sejalan dengan pemikiran yang selama ini ditanamkan pada masyarakat bahwa bank syariah adalah benar adanya sebagai bank yang menjalankan prinsip-prinsip syariah.

Pengelola bank syariah tidak hanya harus cakap dalam bidang perbankan saja, melainkan juga harus cakap, profesional, beretika dan berakhlak baik sesuai tuntunan syariah. masyarakat memiliki harapan kepada bank syariah beserta praktisi nya untuk selalu beroperasional sesuai dengan nilai-nilai tuntunan ajaran agama Islam. Hal ini sangat diharapkan oleh masyarakat yang memilih bank syariah sebagai alternatif pengelola dana yang bebas dari riba. Harapan masyarakat yang demikian itu tidak sejalan dengan banyaknya tindakan-tindakan tidak adil yang secara sengaja dilakukan oleh praktisi bank syariah itu sendiri. Tindakan-tindakan tidak adil yang dilakukan tersebut diantaranya adalah tindakan pencurian, skimming, korupsi, penipuan, pencairan dana untuk pembiayaan fiktif, pencurian data nasabah, dan tindakan-tindakan negatif lainnya yang dilakukan oleh berbagai tingkatan di bank syariah mulai dari karyawan level bawah, pihak manajemen sampai pihak pemilik, yang bertujuan untuk mendapatkan keuntungan pribadi 
Tindakan- tindakan negatif ataupun penyimpangan yang dicoba secara terencana serta merugikan bank, nasabah, serta pihak lain menderita kerugian secara langsung ataupun tidak langsung disebut dengan sebutan fraud (Kismawadi, Muddatstsir, \& Hamid, 2020). Surat Edaran Nomor. 13/ 28/ DPNP Tahun 2011 menimpa Penerapan Strategi Anti Fraud untuk Bank Umum, melaporkan fraud selaku aksi penyimpangan ataupun pembiaran yang terencana dicoba untuk mengelabui, menipu, ataupun memanipulasi bank, nasabah, ataupun pihak lain yang terjalin di area bank serta/ ataupun memakai fasilitas bank sehingga menyebabkan bank, nasabah, ataupun pihak lain mengidap kerugian baik secara langsung ataupun tidak langsung (Kismawadi et al., 2020). Dari kajian laporan tahunan Bank Umum Syariah, ditemui nyaris seluruhnya melaporkan permasalahan fraud yang dilakukan oleh internal bank itu sendiri, baik itu dicoba oleh pihak direksi, karyawan tetap ataupun karyawan tidak tetap. Sehingga perihal ini membuktikan kalau bank syariah tidak lepas dari aksi fraud.

Rezaae menyatakan bahwa terjadinya fraud antara lain dipicu oleh kurangnya tata kelola perusahaan yang baik, tidak adanya komite audit/ tidak efektif, dan lemahnya sistem pengendalian internal. Jika dilihat pada kasus fraud yang terjadi pada Bank Umum Syariah, hal tersebut tidaklah sesuai karena berdasarkan laporan tahunan (annual report), Bank Umum Syariah di Indonesia telah melaporkan penerapan Good Corporate Governance yang secara umum baik yang mana dilihat dari nilai self assessment yang dilaporkan, komite audit bank umum syariah telah terbentuk dan berjalan dengan efektif, serta bank umum syariah memiliki sistem pengendalian internal melalui Whistleblowing System yang cukup memadai. Terpenuhinya komponen-komponen tersebut tidak menjamin bahwa Bank Umum Syariah dapat terbebas dari kejadian fraud khususnya fraud yang dilakukan oleh pihak internal. Contohnya pada Bank Muamalat Indonesia dan Bank Syariah Mandiri, kedua bank tersebut memiliki total kasus fraud tertinggi yang berdampak signifikan dibandingkan bank umum syariah lainnya selama periode 2016-2019.

Berdasarkan pemaparan permasalahan diatas, maka menarik untuk dikaji lebih dalam mengenai peranan komite audit, Good Corporate Governance dan Whistleblowing System terhadap fraud bank umum syariah, agar dapat diketahui alasan mengapa masih terjadi banyak kasus fraud meskipun komponen komite audit, Good Corporate Governance dan Whistleblowing System telah terpenuhi dengan baik.

\section{TINJAUAN LITERATUR}

\section{Fraud}

Menurut Weygandt, dkk., "fraud is a dishonest act by an employee that results in a personal benefit to the employee at a cost to the employer". Kecurangan adalah suatu perilaku yang tidak jujur yang memberikan keuntungan pribadi untuk karyawan yang dibebankan kepada majikan(Hasibuan, Annam, \& Nofinawati, 2020). Ada tiga kategori besar dari fraud yaitu, kecurangan yang terdeteksi dan diekspos secara public, kecurangan yang terdeteksi dalam organisasi, tetapi tidak diekspos secara publik, serta kecurangan yang belum terdeteksi (Kaunang, 2012). Para akuntan membedakan fraud dalam beberapa kategori, seperti 
penyelewengan aset,fraudulent statement, dan korupsi. Penyelewengan aset menjadi salah saty jenis fraud yang paling umum terjadi di perusahaan termasuk bank syariah. untuk melancarkan kejahatan fraud, pelaku/ fraudster biasanya berkolusi dengan orang lain.

Terdapat faktor-faktor yang mempengaruhi terjadinya fraud pada suatu instansi. Menurut Rezaee, beberapa faktor yang ada pada manajemen yang memungkinkan terjadinya fraud diantaranya adalah kurangnya tata kelola perusahaan yang bertanggung jawab (Good Corporate Governance), dan tidak adanya komite audit atau komite audit yang dimiliki perusahaan berjalan tidak efektif, ketiadaan struktur pengawasan atau pengendalian internal yang memadai dan efektif. Menurut Komite Nasional Kebijakan Governance, Whistleblowing System adalah bagian dari sistem pengendalian internal dalam mencegah terjadinya praktik fraud serta memperkuat penerapan Good Corporate Governance (KNKG, 2008). Jika fungsi Whistleblowing System tidak memadai dan tidak efektif, maka akan ada kemungkinan terjadinya fraud.

Baris pertama pertahanan terhadap terjadinya fraud (kecurangan) adalah dengan sistem dari tata kelola yang dibangun dengan baik (Good Corporate Governance), manajemen resiko, pengendalian internal, serta manajemen bertanggung jawab termasuk dewan dan komite audit (Wind, 2014). Tindakan fraud juga dapat dicegah dengan cara mengefektifkan fungsi Whistleblowing System/ pelaporan pelanggaran dan audit investigasi (Putra, O, \& Maemunah, 2017), serta membangun budaya perusahaan yang menghargai kejujuran dan menjunjung tinggi nilai-nilai etika (Priyanto \& Aryati, 2016).

\section{Komite Audit}

Komite audit merupakan salah satu komponen penting yang membentuk mekanisme tata kelola internal perusahaan bersama-sama dewan direksi, dewan komisaris, manajemen dan fungsi pengendalian internal (Anugrah, 2019) dalam hal ini, komite audit berada di barisan depan dalam pencegahan dan deteksi dari penipuan keuangan(Kismawadi et al., 2020). Berbagai penipuan yang terjadi pada perusahaan-perusahaa memiliki beberapa kesamaan yang berkaitan dengan komite audit seperti, kurangnya independensi para anggota komite audit, ketidakberadaan komite audit atau tidak aktif, serta kurangnya pengalaman anggota dewan (Hall \& Singleton, 2007).

\section{Komposisi Komite Audit}

Komposisi komite audit disesuaikan dengan kompleksitas perusahaan dengan tetap memperhatikan efektivitas dalam pengambilan keputusan (KNKG, 2006). Menurut Mennon dan Williams sebagaimana dikutip dalam oleh Rusdiyanto dan Elan menyatakan bahwa semakin banyak komite audit berisi direksi independen maka akan semakin efektif mengatasi kecurangan (Rusdiyanto \& Elan, 2019). Dechow, dkk. dan Beasley, dkk. meneliti kecurangan pada perusahaan yang berbeda yang hasilnya menunjukkan bahwa perusahaan yang memiliki anggota independen lebih sedikit diantara komite audit menunjukkan kecenderungan terjadinya kecurangan yang lebih tinggi(Rusdiyanto \& Elan, 2019). 
$\mathrm{H}_{1}=$ Komposisi komite audit berpengaruh terhadap fraud.

\section{Rapat Komite Audit}

POJK No. 55/ POJK.04/2015 menyatakan rapat komite audit harus dilaksanakan secara berkala paling sedikit 1 kali dalam 3 bulan. Rapat komite audit dapat diselenggarakan apabila dihadiri oleh lebih dari $1 / 2$ jumlah anggota. Menurut Abott, dkk yang dikutip oleh oleh Rusdiyanto dan Elan menyatakan bahwa semakin banyak komite audit bertemu dan memastikan anggotanya melakukan pekerjaan yang diminta oleh mereka demi kepentingan perusahaan, maka akan semakin kecil kemungkinan kecurangan(Rusdiyanto \& Elan, 2019).

$\mathrm{H}_{2}=$ Rapat komite audit berpengaruh terhadap fraud.

\section{Masa Tugas Komite Audit}

Menurut Beasley yang dikutip oleh Rusdiyanto dan Elan, masa jabatan anggota komite audit yang lebih pendek akan berjalan tidak efektif dalam mencegah kecurangan pelaporan keuangan (Rusdiyanto \& Elan, 2019). Dengan masa jabatan komite audit yang lebih lama, maka komite audit akan lebih memahami seluk beluk perusahaan serta mengenal karakteristik para manajer yang diawasi oleh komite audit sehingga komite audit yang masa jabatannya lebih lama tidak akan mudah dikelabui oleh manajer.

$\mathrm{H}_{3}=$ Masa tugas komite audit berpengaruh terhadap fraud.

\section{Good Corporate Governance}

Good Corporate Governance adalah aturan, standar dan organisasi di bidang ekonomi yang mengatur perilaku pemilik perusahaan, direktur dan manajer serta perincian dan penjabaran tugas dan wewenang serta pertanggung jawabannya kepada investor (pemegang saham dan kreditur) (Rusdiyanto \& Elan, 2019). Self Assessment digunakan sebagai paradigma untuk mengukur atau menilai penerapan tata kelola/ Good Corporate Governance pada bank syariah. Semakin baik penerapan tata kelola perusahaan/ Good Corporate Governance maka diharapkan semakin sedikit jumlah fraud yang terjadi pada bank syariah (Kismawadi et al., 2020).

$\mathrm{H}_{4}=$ Good Corporate Governance berpengaruh terhadap fraud.

\section{Whistleblowing System}

Whistleblowing System adalah pengungkapan pelanggaran atau perbuatan yang melawan hukum, perbuatan tidak etis atau tidak bermoral dan perbuatan lain yang dapat merugikan organisasi kepada pimpinan organisasi maupun pemangku kepentingan, yang dilakukan oleh karyawan atau pimpinan organisasi kepada pimpinan organisasi atau lembaga lain yang dapat mengambil tindakan atas pelanggaran tersebut (KNKG, 2008). Pimpinan perusahaan memiliki kesempatan untuk mengatasi permasalahan secara internal terlebih dahulu, sebelum permasalahan tersebut tersebar ke publik dan dapat mempengaruhi reputasi perusahaan (Wardani dan Suhalni). Menurut Ahmad, dkk. sebagaimana dikutip oleh Early Ridho Kismawadi, dkk. Whistleblowing adalah salah satu outlet paling penting untuk 
melaporkan kecurangan organisasi.Efektifitas penerapan Whistleblowing System dapat dilihat dari banyaknya jumlah kecurangan yang berhasil terdeteksi serta waktu penindakan atas laporan kecurangan lebih singkat.

$\mathrm{H}_{5}=$ Whistleblowing System berpengaruh terhadap fraud.

\section{METODE PENELITIAN}

Penelitian ini berjenis penelitian kuantitatif dengan menggunakan populasi bank umum syariah di Indonesia yang tercatat di OJK tahun 2016-2019. Teknik pengambilan sampel dengan metode sampling jenuh yang mana mengambil seluruh anggota populasi untuk dijadikan sebagai sampel. Sehingga ada 14 bank umum syariah yang dijadikan sampel dengan unit analisis sebanyak 56 data. Data diperoleh dari laporan tahunan masing-masing bank umum syariah periode 2016-2019. Pengukuran variabel dalam penelitian ini dijelaskan dalam tabel 1 sebagai berikut:

Tabel 1. Pengukuran Variabel

\begin{tabular}{|c|c|c|}
\hline No. & Nama Variabel & Pengukuran \\
\hline 1. & Fraud & $\begin{array}{l}\text { Membagi data menjadi } 3 \text { kategorisasi: } \\
\begin{array}{l}\text { a. } \text { Tidak ada Kasus }=0 \text { kasus } \\
\text { b. Kategori rendah }=1 \text { ketika jumlah kasus }<17 \\
\text { c. Kategori tinggi }=2 \text { ketika jumlah kasus }>18 \text { kasus }\end{array}\end{array}$ \\
\hline 2. & $\begin{array}{l}\text { Komposisi komite } \\
\text { audit }\end{array}$ & $\begin{array}{l}\text { Komposisi komite audit } \\
\qquad=\frac{\text { Jumlah komite audit independen }}{\text { Jumlah seluruh anggota komite audit }} \times 100 \%\end{array}$ \\
\hline 3. & $\begin{array}{l}\text { Rapat komite } \\
\text { audit }\end{array}$ & $\begin{array}{l}\text { Rapat komite audit } \\
\qquad=\frac{\text { Rata }- \text { rata tingkat kehadiran rapat }}{\text { Jumlah seluruh rapat komite audit }} \times 100 \%\end{array}$ \\
\hline 4. & $\begin{array}{l}\text { Good Corporate } \\
\text { Governance }\end{array}$ & $\begin{array}{l}\text { Memberi nilai sesuai hasil Self Assessment penerapan Good } \\
\text { Corporate Governance dengan rentang antara } 1-5 \text {. Nilai } 1=\text { sangat } \\
\text { baik, } 2=\text { baik, } 3=\text { cukup, } 4=\text { kurang, } 5=\text { sangat kurang }\end{array}$ \\
\hline 5. & $\begin{array}{l}\text { Whistleblowing } \\
\text { System }\end{array}$ & $\begin{array}{l}\text { Memberi kode "0" jika BUS belum memenuhi mekanisme } \\
\text { Whistleblowing System menurut KNKG dan kode "1" jika sudah } \\
\text { memenuhi mekanisme Whistleblowing System menurut KNKG }\end{array}$ \\
\hline
\end{tabular}

\section{HASIL DAN PEMBAHASAN}

Data yang diolah dalam penelitian ini ditunjukkan dalam bentuk analisis statistik deskriptif, yang disajikan pada Tabel 2 dan Tabel 3 berikut:

Tabel 2. Hasil Analisis Statistik Deskriptif Variabel dengan Skala Numerik

\begin{tabular}{cccccc}
\hline Variabel & N & Mean & $\begin{array}{c}\text { Standar } \\
\text { deviasi }\end{array}$ & Min & Max \\
\hline Komposisi komite audit & 56 & $49,51 \%$ & 15,239 & $25 \%$ & $80 \%$ \\
\hline
\end{tabular}




\begin{tabular}{llllll}
\hline Rapat komite audit & 56 & $74,15 \%$ & 19,328 & $30 \%$ & $100 \%$ \\
\hline
\end{tabular}

Tabel 3. Hasil Analisis Statistik Deskriptif Variabel dengan Skala Numerik

\begin{tabular}{lccc}
\hline Variabel & ategori & Jumlah & Presentase \\
\hline Fraud & 0 & 16 & $28,6 \%$ \\
& 1 & 34 & $60,7 \%$ \\
& 2 & 6 & $10,7 \%$ \\
\hline Masa tugas komite audit & 0 & 24 & $42,9 \%$ \\
& 1 & 32 & $57,1 \%$ \\
\hline Good Corporate Governance & 1 & 9 & $16,1 \%$ \\
& 2 & 35 & $62,5 \%$ \\
& 3 & 12 & $21,4 \%$ \\
& 4 & 0 & $0 \%$ \\
& 5 & 0 & $0 \%$ \\
\hline
\end{tabular}

Tabel 4. Hasil regresi logistik

\begin{tabular}{lccrr}
\hline \multicolumn{1}{c}{ Variabel } & Arah & $\begin{array}{c}\text { Nomor } \\
\text { hipotesis }\end{array}$ & Koefisien & Signifikansi \\
\hline Komposisi komite audit & - & 1 & $-0,046$ & $0,031^{* *}$ \\
Rapat komite audit & - & 2 & $-0,016$ & 0,314 \\
Masa tugas komite audit & - & 3 & $-1,333$ & $0,035^{* *}$ \\
Good Corporate Governance & - & 4 & $-2,378$ & $0,034^{* *}$ \\
Whistleblowing System & - & 5 & $-0,857$ & 0,207 \\
\hline
\end{tabular}

Sumber: data sekunder yang diolah, 2021.

Berdasarkan hasil regresi logistik yang tersaji pada Tabel 4, maka diperoleh fungsi logit sebagai berikut:

$$
\begin{aligned}
& \operatorname{logit}(p 1)=-7,059-0,046_{x 1}-1,333_{x 3}-2,738_{x 4=1} \\
& \operatorname{logit}(p 2)=-3,295-0,046_{x 1}-1,333_{x 3=0}-2,738_{x 4=1}
\end{aligned}
$$

Tabel 5. Nilai Pseudo R Square

\begin{tabular}{ll}
\hline Cox and Snell & 0,242 \\
\hline Nagelkerke & 0,290 \\
\hline McFadden & 0,154
\end{tabular}

Link function: Logit.

Berdasarkan Tabel 5 diperoleh nilai Nagelkerke sebesar 0,290. Artinya, variabel dalam model penelitian ini mampu menjelaskan variasi kejadian fraud sebesar $29 \%$, sedangkan $71 \%$ sisanya dijelaskan oleh variabel lain di luar model penelitian. 
Tabel 6. Nilai Odds Ratio

\begin{tabular}{lcc}
\hline \multicolumn{1}{c}{ Variabel } & Estimate $(\boldsymbol{\beta})$ & Odds ratio \\
\hline Threshold $(\mathrm{Y}=0)$ & $-7,059$ & \\
Threshold $(\mathrm{Y}=1)$ & $-3,295$ & \\
Komposisi Komite Audit & $-0,046$ & 0,955 \\
Masa Tugas Komite Audit & $-1,333$ & 0,264 \\
Good Corporate Governance & $-2,378$ & 0,092 \\
\hline
\end{tabular}

Komposisi komite audit:

$$
\begin{aligned}
& p 1=\frac{\operatorname{Exp}(-7,059-0,046)}{1+\operatorname{Exp}(-7,059-0,046)}=\frac{0,000821}{1+0,000821}=0,000821 \\
& p 1+p 2=\frac{\operatorname{Exp}(-3,295-0,046)}{1+\operatorname{Exp}(-3,295-0,046)}=\frac{0,035401}{1+0,035401}=0,035401 \\
& \text { Sehingga } p 2 \text { adalah } 0,035401-0,000821=0,03458
\end{aligned}
$$

Kenaikan komposisi komite audit independen mampu menurunkan probabilitas kasus fraud tinggi sebesar 0,955 kali, mengurangi probabilitas tidak terjadi kasus fraud sebesar 0,00821 kali dan mengurangi probabilitas kasus fraud rendah sebesar 0,03458 kali. Masa Tugas Komite Audit:

$$
\begin{gathered}
p 1=\frac{\operatorname{Exp}(-7,059-1,333)}{1+\operatorname{Exp}(-7,059-1,333)}=\frac{0,000227}{1+0,000227}=0,000227 \\
p 1+p 2=\frac{\operatorname{Exp}(-3,295-1,333)}{1+\operatorname{Exp}(-3,295-1,333)}=\frac{0,009774}{1+0,009774}=0,009679
\end{gathered}
$$

Sehingga $p 2$ adalah $0,009679-0,000227=0,009452$

Kenaikan masa tugas komite audit mampu menurunkan probabilitas terjadinya kasus fraud tinggi sebesar 0,264, menurunkan probabilitas tidak terjadi kasus fraud sebesar 0,000227 kali dan menurunkan probabilitas terjadinya kasus fraud rendah sebesar 0,009452 kali.

Good Corporate Governance:

$$
\begin{aligned}
& p 1=\frac{\operatorname{Exp}(-7,059-2,738)}{1+\operatorname{Exp}(-7,059-2,378)}=\frac{0,000056}{1+0,000056}=0,000056 \\
& p 1+p 2=\frac{\operatorname{Exp}(-3,295-2,738)}{1+\operatorname{Exp}(3,295-2,738)}=\frac{0,002398}{1+0,002398}=0,0023924 \\
& \text { Sehingga } p 2 \text { adalah } 0,0023924-0,0000556=0,002337
\end{aligned}
$$

Kenaikan Good Corporate Governance mampu menurunkan probabiltas terjadinya kasus fraud tinggi sebesar 0,092 kali, menurunkan probabilitas tidak terjadinya kasus fraud sebesar 0,000056 kali dan menurunkan probabilitas terjadinya kasus fraud rendah sebesar 0,002337 kali. 


\section{Pengaruh Komposisi Komite Audit Independen terhadap Fraud}

Hipotesis pertama dalam penelitian ini berbunyi bahwa komposisi komite audit berpengaruh terhadap fraud. Berdasarkan hasil uji regresi logistik yang ditunjukkan pada Tabel 3 dapat ditarik kesimpulan bahwa hipotesis pertama diterima, karena memiliki nilai yang signifikan terhadap fraud. Koefisien regresi logistik ordinal yang diperoleh adalah sebesar 0,046 satuan. Koefisien tersebut bernilai negatif sehingga terjadi hubungan yang tidak searah antara komposisi komite audit dengan probabilitas terjadinya fraud, artinya semakin besar komposisi komite audit berasal dari pihak independen maka akan menurunkan probabilitas terjadinya kasus fraud.

Diterimanya hipotesis yang pertama dalam penelitian ini menunjukkan bahwa ditingkatkannya komposisi komite audit yang berasal dari pihak independen dapat mengurangi keterjadian kasus fraud pada Bank Umum Syariah. Pengaruh yang dihasilkan tersebut karena komite audit yang berasal dari pihak independen telah diangkat dan dipilih berdasarkan keahlian ilmu dan pengalaman yang dimiliki dalam bidang akuntansi, keuangan dan perbankan syariah. Sehingga dengan berbekal ilmu dan pengalaman yang dimiliki oleh komite audit tersebut, nantinya mampu meningkatkan pengawasan baik secara langsung ataupun melalui perantara auditor internal, auditor eksternal, maupun divisi anti fraud untuk sebisa mungkin hasil audit atau temuannya tidak diintervensi oleh pihak-pihak manajemen bank. Independensi seorang komite audit juga menyangkut tentang kejujuran, mental yang bebas dari pengaruh, tidak dikendalikan oleh pihak lain, juga tidak tergantung pada orang lain. Komite audit yang independen tidak akan memihak ke siapapun terlebih pada pelaku fraud. Pada akhirnya independensi yang dimiliki oleh komite audit, akan menciptakan transparansi atas kejadian fraud yang dengan cerdik disembunyikan oleh pelaku fraud (fraudster).

Dengan kejujuran dan mental bebas dari pengaruh pihak manapun yang dimiliki oleh komite audit, dapat membuahkan pendeteksian kasus fraud yang lebih awal sehingga dampak yang ditimbulkan dari fraud tersebut dapat diminimalkan. Dari mekanisme yang terbangun tersebut, maka probabilitas terjadinya kasus fraud dapat diminimalkan dengan kehadiran komite audit yang independen. Semakin banyak komite audit berasal dari pihak independen maka akan semakin efektif dalam mengurangi keterjadian kasus fraud pada Bank Umum Syariah atau bahkan kasus fraud mampu ditekan hingga zero cases.

Hasil penelitian ini mendukung penelitian Mennon dan Williams sebagaimana dikutip dalam Rusdiyanto, yang menyatakan bahwa semakin banyak komite audit berisi direksi independen, maka akan semakin efektif mengatasi kecurangan(Rusdiyanto \& Elan, 2019). Dan bertolak belakang dengan hasil penelitian yang dilakukan oleh Andrian Budi Prasetya yang menyatakan bahwa jumlah anggota komite audit independen tidak berpengaruh signifikan terhadap kemungkinan kecurangan laporan keuangan. Dan memberikan alasan bahwa pembentukan komite audit independen oleh perusahaan kemungkinan hanya dilakukan untuk memenuhi regulasi saja. 


\section{Pengaruh Rapat Komite Audit terhadap Fraud}

Hipotesis kedua dalam penelitian ini berbunyi bahwa rapat komite audit berpengaruh terhadap fraud. Berdasarkan hasil regresi logistik yang ditunjukkan pada Tabel 3 dapat disimpulkan hipotesis kedua ditolak karena memiliki nilai yang tidak signifikan terhadap fraud. Koefisien regresi logistik ordinal yang diperoleh adalah sebesar $-0,016$. Koefisien tersebut bernilai negatif sehingga terjadi hubungan yang tidak searah antara rapat komite audit dengan probabilitas terjadinya fraud. Artinya, semakin sering rapat komite audit diselenggarakan dengan tingkat kehadiran yang optimal dari anggota komite audit, maka akan menurunkan probabilitas terjadinya kasus fraud.

Ditolaknya hipotesis kedua dalam penelitian ini menunjukkan bahwa seringnya rapat komite audit diselenggarakan berpengaruh negatif terhadap kemungkinan terjadinya kasus fraud pada Bank Umum Syariah di Indonesia, namun pengaruh yang diberikan tersebut tidak secara signifikan. Sehingga semakin sering rapat diselenggarakan tidak secara signifikan mampu mengurangi probabilitas terjadinya fraud. Pengaruh yang dihasilkan tersebut karena komite audit adalah komite yang dibentuk oleh dan bertanggung jawab kepada dewan komisaris dalam melaksanakan tugas dan fungsi dewan komisaris. Dapat dikatakan bahwa kedudukan komite audit adalah sebagai "mata" dan "telinga" dewan komisaris untuk mengawasi jalannya bank syariah. Sehingga berkaitan dengan adanya kecurigaan atau adanya temuan awal dugaan kejadian fraud, komite audit akan mengkoordinasikannya bersama dengan dewan komisaris dalam agenda rapat komite audit.

Ketika kecurigaan, ataupun temuan awal atas dugaan fraud yang disampaikan oleh komite audit tersebut tidak mendapatkan respon atau tindak lanjut atau bahkan tidak adanya persetujuan untuk dilakukan penyelidikan lebih lanjut, maka seberapapun seringnya komite audit mengadakan rapat tidak secara efektif akan mengurangi probabilitas terjadinya kasus fraud. Namun rapat komite audit tetap harus dilaksanakan sebagai bentuk tanggung jawab komite audit terhadap dewan komisaris khususnya berkaitan dengan penyusunan rencana/ strategi anti fraud di masa yang akan datang.

Hasil penelitian ini sejalan dengan penelitian Andrian Budi Prasetya yang menyimpulkan bahwa jumlah rapat komite audit tidak berpengaruh signifikan terhadap kecurangan pelaporan keuangan (Prasetyo, 2014). Dan sejalan pula dengan penelitian Gading Ruchiatna, dkk. yang menyimpulkan bahwa rapat komite audit tidak memiliki pengaruh terhadap fraudulent financial reporting (Ruchiatna, Puspa Midiastuty, \& Suranta, 2020).

\section{Pengaruh Masa Tugas Komite Audit terhadap Fraud}

Hipotesis ketiga dalam penelitian ini berbunyi bahwa masa tugas komite audit berpengaruh terhadap fraud. berdasarkan hasil regresi logistik ordinal yang ditunjukkan pada Tabel 3 dapat disimpulkan hipotesis ketiga diterima karena memiliki nilai signifikan terhadap fraud. Koefisien regresi logistik ordinal yang diperoleh adalah sebesar -1,333 satuan. Koefisien tersebut bernilai negatif sehingga terjadi hubungan yang tidak searah antara masa tugas 
komite audit dengan probabilitas terjadinya kasus fraud. Artinya, semakin lama masa tugas komite audit maka akan menurunkan kemungkinan terjadinya kasus fraud pada Bank Umum Syariah.

Diterimanya hipotesis yang ketiga dalam penelitian ini menunjukkan bahwa lamanya masa tugas komite audit berpengaruh terhadap probabilitas terjadinya kasus fraud pada Bank Umum Syariah di Indonesia. Pengaruh yang dihasilkan tersebut karena pada dasarnya komite audit membutuhkan waktu yang tidak singkat untuk mengenal lingkungan perusahaan bank syariah termasuk budaya, nilai, norma dan sumber daya manusianya. Jika komite audit telah mengenal dengan baik lingkungan perusahaan bank syariah yang menjadi tanggung jawabnya, maka akan semakin mudah bagi mereka untuk menangkap gambaran awal sebagai langkah identifikasi celah fraud potensial. Dengan masa tugas komite audit yang lebih lama, akan menciptakan hubungan yang sinergis antara komite audit dengan manajemen bank syariah dan auditor internal sehingga pengawasan yang dilakukan pun akan lebih efektif dalam mengurangi keterjadian kasus fraud pada Bank Umum Syariah di Indonesia. Hasil penelitian ini mendukung penelitian Andrian Budi Prasetya yang menyimpulkan bahwa semakin lama masa jabatan anggota komite audit maka secara efektif akan mengurangi terjadinya tindak kecurangan pelaporan keuangan (Prasetyo, 2014).

\section{Pengaruh Good Corporate Governance terhadap fraud}

Hipotesis keempat dalam penelitian ini berbunyi bahwa Good Corporate Governance berpengaruh terhadap fraud. berdasarkan hasil regresi logistik ordinal yang ditunjukkan pada Tabel 3 dapat disimpulkan bahwa hipotesis keempat diterima karena memiliki nilai yang signifikan. Koefisien regresi logistik ordinal yang diperoleh variabel Good Corporate Governance adalah sebesar $-2,378$. Koefisien tersebut bernilai negatif sehingga terjadi hubungan yang tidak searah antara Good Corporate Governance dengan probabilitas terjadinya kasus fraud. Artinya, semakin baik Good Corporate Governance diterapkan maka akan menurunkan probabilitas terjadinya kasus fraud pada Bank Umum Syariah.

Diterimanya hipotesis yang ke empat dalam penelitian ini menunjukkan bahwa semakin baiknya penerapan Good Corporate Governance akan berpengaruh terhadap probabilitas keterjadian kasus fraud. Pengaruh yang dihasilkan tersebut karena nilai-nilai yang diterapkan dalam Good Corporate Governance dapat digunakan sebagai alat kontrol bagi stakeholders untuk mengawasi serta mengendalikan kinerja bank syariah agar berjalan sesuai dengan target dan tidak menimbulkan kerugian pada stakeholders. Sehingga dengan alat kontrol berupa Good Corporate Governance tersebut dapat mencegah dan mengurangi keterjadian kasus fraud yang melibatkan pihak manajemen pada bank umum syariah. Salah satu komponen dalam Good Corporate Governance adalah adanya transparansi. Ketika bank umum syariah berkomitmen bersama untuk mengedepankan transparansi operasional, maka kecil kemungkinan ada pihak yang akan merenungkan skema untuk melakukan tindakan fraud. 
Hasil penelitian ini tidak relevan dengan penelitian yang dilakukan oleh Hilmi Faiqoh yang menyimpulkan bahwa Good Corporate Governance belum menjadi faktor yang dapat mempengaruhi pencegahan fraud (Faiqoh, 2019). Dan juga tidak relevan dengan penelitian Ayu Irmasari yang menyimpulkan bahwa Good Corporate Governance tidak berpengaruh terhadap fraud (Raharjanti, 2018).

\section{Pengaruh Whistleblowing System terhadap fraud}

Hipotesis kelima dalam penelitian ini berbunyi bahwa whistleblowing system berpengaruh terhadap fraud. berdasarkan hasil regresi logistik ordinal yang ditunjukkan pada Tabel 3 dapat disimpulkan bahwa hipotesis kelima ditolak, karena tidak memiliki nilai yang signifikan. Koefisien regresi logistik ordinal yang diperoleh adalah sebesar $-0,856$. Koefisien tersebut bernilai negatif sehingga terjadi hubungan yang tidak searah antara whistleblowing system dengan probabilitas terjadinya fraud. Semakin efektif whistleblowing system maka akan menurunkan probabilitas terjadinya kasus fraud.

Ditolaknya hipotesis kelima dalam penelitian ini menunjukkan bahwa keefektifan pengadaan fasilitas whistleblowing system dengan melihat lengkap atau tidaknya mekanisme fasilitas whistleblowing system memiliki pengaruh yang negatif terhadap probabilitas terjadinya kasus fraud pada Bank Umum Syariah, namun pengaruh yang diberikan tersebut tidak signifikan. Sehingga selengkap apapun mekanisme penyampaian whistleblowing system tidak secara signifikan mampu mengurangi probabilitas terjadinya fraud.

Tidak signifikannya pengaruh yang dihasilkan tersebut karena whistleblowing system yang difasilitasi dengan baik tidak cukup efektif jika tidak diiringi dengan partisipasi aktif baik dari karyawan maupun pihak eksternal untuk melaporkan kecurangan yang diketahui. Sehingga whistleblowing system yang salah satu fungsinya untuk membuat efek takut kepada pelaku kecurangan tidak dapat berhasil karena saksi atas tindakan kecurangan tersebut bersikap pasif untuk melaporkan tindakan penyimpangan yang diketahui. Selain itu, whistleblowing system berada dibawah pengawasan komite audit dan laporan-laporan yang masuk atas dugaan terjadinya tindakan fraud melalui sistem ini akan ditindaklanjuti oleh audit internal. Audit internal sendiri cenderung lebih dekat pada pihak manajemen bank syariah dan apabila antara auditor internal dengan pihak manajemen Bank Umum Syariah telah membangun kerjasama untuk menutupi kasus fraud yang terjadi pada internal bank syariah itu, maka adanya whistleblowing system tidak akan efektif mengurangi kasus fraud.

Hasil penelitian ini sesuai dengan penelitian Mohe Nur Cahyo dan Sulhani yang menyatakan bahwa penerapan whistlebowing system tidak berpengaruh terhadap pengungkapan kecurangan. Alasan yang diberikan Mohe Nur Cahyo dan Sulhani adalah jika dilihat dari sudut pandang perusahaan, pengungkapan kecurangan dalam laporan tahunan merupakan bagian dari bad news sehingga ketika ada laporan yang masuk dalam sistem whistleblowing maka perusahaan cenderung akan bersikap proaktif dalam menyelesaikan kasus fraud tersebut (Nur Cahyo \& Sulhani, 2017). 
Hasil penelitian ini tidak sesuai dengan penelitian Anitaria Siregar yang menyimpulkan bahwa semakin efektif whistleblowing system diaplikasikan maka dapat mengurangi kecurangan (Siregar \& Surbakti, 2020). Dan juga tidak sejalan dengan penelitian Luh Utami, dkk yang menyatakan bahwa whistleblowing system memiliki pengaruh yang negatif dan signifikan, dengan alasan bahwa pengadaan fasilitas whistleblowing system dapat meningkatkan efektivitas audit internal dalam mengungkap kasus kecurangan yang terjadi (Utami, Handajani, \& Hermanto, 2019).

\section{KESIMPULAN}

Hasil penelitian menunjukkan bahwa variabel komposisi komite audit independen, masa tugas komite audit dan Good Corporate Governance memiliki hubungan yang negatif signifikan terhadap fraud. Sedangkan variabel rapat komite audit dan whistleblowing system berpengaruh negatif tidak signifikan terhadap fraud. Variabel independen komposisi komite audit, rapat komite audit, masa tugas komite audit, Good Corporate Governance, dan whistleblowing system mampu menjelaskan variasi fraud sebesar $29 \%$ sedangkan $71 \%$ dijelaskan variabel lain yang tidak diteliti. Rendahnya pengaruh yang diberikan tersebut kemungkinan disebabkan oleh kurang optimalnya tindak lanjut dari rapat komite audit yang diselenggarakan serta kurangnya independensi auditor internal dalam mengelola laporan fraud. Sehingga bank umum syariah harus mengoptimalkan fungsi divisi anti fraud dan menghadirkan divisi tersebut dalam penyelenggaraan rapat untuk menguatkan hasil temuan atas dugaan/ kejadian fraud, serta meningkatkan independensi auditor internal dalam mengelola laporan dugaan fraud yang masuk melalui whistleblowing system. Diharapkan penelitian selanjutnya memperbarui pengukuran fraud dan melihatnya dari faktor-faktor lain baik yang berasal dari keuangan seperti rasio maupun faktor non keuangan.

\section{REFERENSI}

Anugrah, R. (2019). Peran Good Corporate Governance dalam Pencegahan Fraud. Journal of Chemical Information and Modeling, 53(1), 287.

Faiqoh, H. (2019). Pengaruh Sistem Pengendalian Internal dan Good Corporate Governance Terhadap Pencegahan Fraud. Universitas Islam Sultan Agung.

Hall, J. A., \& Singleton, T. (2007). Audit Teknologi Informasi dan Assurance (2 ed.). Jakarta Selatan: Salemba Empat.

Hasibuan, A. N., Annam, R., \& Nofinawati. (2020). Audit Bank Syariah. 2020: Kencana.

Kaunang, A. F. (2012). Pedoman Audit Internal. Jakarta: PT. Bhuana Ilmu Populer.

Kismawadi, E. R., Muddatstsir, U. D. Al, \& Hamid, A. (2020). Fraud Pada Lembaga Keuangan dan Lembaga Non Keuangan. Depok: Rajawali Pers.

KNKG. (2006). Pedoman Umum Good Corporate Governance Indonesia.

KNKG. (2008). Pedoman Sistem Pelaporan Pelanggaran - SPP (Whistleblowing system- WBS).

Nur Cahyo, M., \& Sulhani, S. (2017). Analisis Empiris Pengaruh Efektifitas Komite Audit, Efektifitas Internal Audit, Whistleblowing System, Pengungkapan Kecurangan dan Reaksi Pasar. Jurnal Dinamika Akuntansi dan Bisnis, 4(2), 249-270.

Prasetyo, A. B. (2014). Pengaruh Karakteristik Komite Audit dan Perusahaan Terhadap 
Kecurangan Pelaporan Keuangan. Jurnal Akuntansi dan Auditing, 11(1), 1-24.

Priyanto, A., \& Aryati, T. (2016). Analisis Pengaruh Budaya Organisasi dan Sistem Pengendalian Internal Terhadap Pendeteksian dan Pencegahan Fraud. Jurnal Informasi, Perpajakan, Akuntansi, dan Keuangan Publik, 11(2), 89. https://doi.org/10.25105/jipak.v11i2.4571

Putra, A. M., O, M. L., \& Maemunah, M. (2017). Pengaruh Audit Investigasi dan Efektivitas Whistleblowing System Terhadap Pencegahan Kecurangan (Fraud) (Survei Pada Perusahaan Badan Usaha Milik Negara di Kota Bandung). Prosiding Akuntansi, (ISSN: 2460-6561), 183-187.

Raharjanti, A. I. (2018). Pengaruh Good Corporate Governance terhadap Internal Fraud pada Unit Usaha Syariah Tahun 2017. Journal of Multidisciplinary Studies, 2(2), 213-222.

Ruchiatna, G., Puspa Midiastuty, P., \& Suranta, E. (2020). Pengaruh Karakteristik Komite Audit terhadap Fraudulent Financial Reporting. Jurnal Akuntansi, Keuangan, dan Manajemen, 1(4), 255-264. https://doi.org/10.35912/jakman.v1i4.52

Rusdiyanto, S., \& Elan, U. (2019). Good Corporate Governance: Teori dan Implementasinya di Indonesia. Bandung: Refika Adhitama.

Siregar, A., \& Surbakti, A. S. (2020). Analisis Pengaruh Whistleblowing System dan Rapat Komite Audit terhadap Jumlah Kecurangan. Balance: Jurnal Akuntansi, Auditing dan Keuangan, 16(1), 21. https://doi.org/10.25170/balance.v16i1.1286

Sodiq, A. (2017). Analisis Swot Perkembangan Perbankan Syariahdi Indonesia. Malia: Journal of Is/amic Banking and Finance, 1(1), 15-28. https://doi.org/10.21043/malia.v1i1.3981

Utami, L., Handajani, L., \& Hermanto. (2019). Efektivitas Komite Audit dan Audit Internal terhadap Kasus Kecurangan dengan Whistleblowing System Sebagai Variabel Pemoderasi Fakultas Ekonomi dan Bisnis Universitas Mataram ( Unram ), NTB , Indonesia. E-Jurnal Akuntansi Universitas Udayana, 26, 1570-1600.

Wind, A. (2014). Forensic Accounting. Jakarta Timur: Dunia Cerdas. 